\title{
Socio-spatial regeneration challenges in Attaba historic market, Cairo - Egypt
}

Aliaa AlSadaty and Dalila ElKerdany

Department of Architecture, Faculty of Engineering, Cairo University, Giza, Egypt

\author{
Neveen Hamza \\ School of Architecture, Planning and Landscape, Newcastle University, \\ Newcastle upon Tyne, UK \\ Sahar Imam and Tamer ElSerafi \\ Department of Architecture, Faculty of Engineering, Cairo University, \\ Giza, Egypt, and \\ Mahmoud Abdallah \\ Faculty of Tourism and Hotels, Mansoura University, Mansoura, Egypt
}

\begin{abstract}
Purpose - This paper aims to address socio-spatial challenges facing the sustainable regeneration of the 19th-century historic covered Attaba market. One of the few remaining historic market buildings in Cairo. Understanding these challenges is crucial as there is a pressing need for these buildings to be included in the national heritage regeneration policies that would foster their role as sustainable socio-economic urban nuclei within the city center.

Design/methodology/approach - The paper detects the socio-spatial transformation of the Attaba market through the comparison of archival material. This is supported by observations on the current sociospatial aspects of the market including forms of interactions, conflicts and interventions of various user groups. A number of 30 semi-structured interviews with traders of the Attaba market were conducted inside the market, along with in-depth observations carried out between 2016 and 2018. Finally, information about local policies toward the market is obtained through interviews with local officials currently managing the market, namely, the Egyptian Endowment Authority and Cairo Governorate.

Findings - The findings reveal a lack of clear regeneration policy and a complete absence of public participation in decision-making. These factors erode the crucial role these markets play in revitalizing the city's socio-economic strength and threaten their tangible and intangible values.
\end{abstract}

(C) Aliaa AlSadaty, Dalila ElKerdany, Neveen Hamza, Sahar Imam, Tamer ElSerafi and Mahmoud Abdallah. Published in Journal of Humanities and Applied Social Sciences. Published by Emerald Publishing Limited. This article is published under the Creative Commons Attribution (CC BY 4.0) licence. Anyone may reproduce, distribute, translate and create derivative works of this article (for both commercial and non-commercial purposes), subject to full attribution to the original publication and authors. The full terms of this licence may be seen at http://creativecommons.org/ licences/by/4.0/legalcode

This paper is part of the research project: "Sustainable Green Markets (SUS-MAR) Regenerating the Urban Historic Core to Sustain Socio-Cultural Heritage and Economic Activities”, funded by the UK Arts and Humanities Research Council (AH/N009169/1), and the Egyptian Sciences and Technology Development Fund (STDF), under the Newton-Mosharafa Fund, (26452). The authors are grateful for both funding bodies in Egypt and UK.

Challenges in Attaba historic market

Received 26 November 2019 Revised 17 May 2020 Accepted 25 May 2020 
JHASS
3,3

218

Originality/value - The paper focuses on one of the understudied building types that, however, represent key opportunities for the sustainable development of their contexts. The paper proposes a framework that can be applied to regenerate the Attaba market and its surroundings. When tested, the framework can be also adjusted and applied to the other historic covered markets in Cairo.

Keywords 19th century covered markets, Attaba market, Khedival Cairo architecture, Sociability of historic markets, Sustainable urban regeneration

Paper type Research paper

\section{Introduction}

Markets have long been the raison d'être of urban, economic and social life in European cities. During late 18th and early 19th century, several European countries witnessed a shift from street markets to covered market buildings and market halls. This shift was supported by several reasons in different countries. For instance, in Britain, with the increase of urban population by the late 18th century, the local government introduced a new market system to facilitate local consumption and to control hygiene levels. At a time when Open Street markets were perceived as chaotic places that attract the worst behaviors in societies and encourage immorality and blasphemy; covered markets were the new trend (Schmiechen and Carls, 1999). Similarly, in France, the provision of centralized locations and contained environments for trading represented a way to ensure hygienic measures and at the same time, to fulfill the need of freeing streets and squares from the many obstacles and crowds caused by markets. An attempt that facilitated the control of urban spaces with tighter surveillance by police forces (Schmiechen and Carls, 1999). These newly established covered markets and market halls were usually linked with large cities where there was the need for specialized sales area, whereas in small towns, open marketplaces were sufficient to the amount of needed trading (Guàrdia and Luis Oyón, 2015).

A first step toward the shift to the then-new architectural typology of covered markets and market halls, during the second half of the 18th century in Great Britain, in France and other European countries was to separate markets activities from the street and insulate them in plots of lands that were not necessary totally covered. With the increase of market forces during the 19th century, the idea of separated marketplaces became more of a necessity and the first totally covered market buildings appeared. They typically consisted of sales cells, efficient circulation spaces and covered roof with openings for ventilation (Schmiechen and Carls, 1999).

The 19th century and the early 20th century represent the golden age for covered markets and market halls. Market buildings introduced an intermediate transition between earlier uncovered marketplaces and present shopping environments including department stores, supermarkets and shopping malls (Guàrdia and Luis Oyón, 2015). Historic covered markets and market halls offered exceptional opportunities for unique trade experiences that fit within their historic contexts, add to the variety of today's shopping experience and play an important role in boosting community engagement, social inclusion and network consolidations (González, 2018).

During the 1970s and 1980s, historic markets witnessed decades of decay as a result of the emerging urban policies, the wide dispersion of the population and the emergence of new neighborhoods with their own trading centers and supermarkets. However, in recent decades, several markets have been rediscovered as tourists' attractions, food meccas and nucleus for the development of their surrounding contexts (González, 2018).

In Cairo, covered markets of the 19th and 20th centuries are rapidly deteriorating due to the lack of regeneration interventions; accordingly, they are witnessing fast transformations 
in their physical and societal roles. These markets, however, can be arguably the key toward a sustainable urban development for their contexts (Hamza et al., 2017).

By investigating the historic building of the Attaba market in Cairo, the study aims at tracing socio-spatial transformations currently taking place in and around the market and the impacts of these activities on the integrity of the historic building fabric. In addition, the study investigates the reasons behind these transformations and detects current local policies steering these changes. By doing so the paper addresses the lack of national policy and strategy for dealing with the socio-spatial features of historic covered market buildings

Challenges in Attaba historic market

in Egypt and the neglect to the potential key role of historic markets in local community development. Accordingly, the outcome of the paper is a proposed framework to deal with the significant historic market and other local markets in Cairo.

Socio-spatial transformation of the Attaba market is studied through the comparison of archival material and present-day data related to the historic building and its surrounding urban areas. This is supported by observations on the social and spatial aspects of the market. This includes different forms of social interactions or conflicts and spatial interventions of various user groups. A number of 30 interviews with traders of the Attaba market were also conducted during working hours inside the market. The in-depth observations and interviews were carried out with photographic documentation of the market through extensive visits to the site in the years from 2016 to 2018. Finally, information about local policies toward the market is obtained through a series of interviews with local officials currently managing the market, represented by the Egyptian Endowment Authority (the current owner of the building) and Cairo Governorate (the administrative body responsible for the building from outside and for its context). More specifically, by the "General Administration for the Preservation of Heritage" in Cairo University. The section, which is - according to their mission stated on their Web page responsible for the architectural and archaeological heritage and the ancient city heritage.

The paper is organized into five sections. Section 2 illustrates the role of historic markets as opportunities for achieving sustainable urban development and regeneration that considers the three pillars of sustainability, namely, the economic, the environmental and the social. Section 3 focuses on the social aspects of markets and their role as spaces for sociability. Section 4 focuses on socio-spatial challenges facing the regeneration of historic markets. Section 5 then presents the case of the Attaba market, in Cairo, Egypt. It starts with illustrating the history of the building and the drastic transformations that took place in and around the market. It shows the current tides of retailers - customers and product displacement; then, it discusses current policies addressing the socio-spatial features of historic local covered markets. Section 6 introduces a proposed framework for the regeneration of the Attaba market and its surrounding context. Finally, the paper is then concluded with a brief outlook of the major findings in Section 7.

\section{Historic markets and sustainable urban development}

A sustainable development strategy usually relies on three pillars, namely, the environmental, the economic and the social (Tweed and Sutherland, 2007). The environmental dimension focuses mainly on the distribution of natural and man-made resources that are fundamental to human survival, including climatic conditions, thermal emissions and the physical context, etc. The economic dimension is considered as the most important prerequisite for any lasting improvement, yet it is not exclusively related to monetary terms. It is increasingly acknowledged that it is neither solely the total growth nor the personal growth of income that guarantees progress for the entire society; qualitative aspects of improvements should be also put into consideration with their quantitative 
JHASS 3,3 counterparts. Finally, the social dimension refers to all aspects related to generational and inter-generational equity, where current generations maximize their benefits from the current cultural capital without risking future generations' rights (Tweed and Sutherland, 2007).

Markets have never been places for the sole role of buying and selling. They have provided places for work and trade, meetings, gatherings and establishing social relationships among the community. Historic market locations were usually selected nearby institutional buildings of power, including town halls, law courts, business premises and religious buildings. Thus, historically, markets have been places for growth, exchange and supply, never isolated from their contexts. They have always played an important role in the environmental, economic and social life of cities (Coleman, 2007). Today, when these markets are endangered, the whole system is affected. Yet, marketplaces carry several opportunities and benefits for sustainable development for their surrounding contexts. They can play an important role in driving a successful environmental, economic and social development for deprived historic city centers and neighborhoods.

Local markets can play a major role in decreasing environmental pollution and energy consumption. This can be done by shortening the supply chain, bringing producers, suppliers and consumers together, and encouraging local products against imported ones. Moreover, markets can be environmentally friendly by reducing their generated waste material and increasing recyclability rates (Costa et al., 2015). For instance, in the Borough Market in London, most stallholders are also producers. The policy followed in this market ensures that $90 \%$ of the waste is recycled. The market also minimizes water use by using a rainwater irrigation system to feed all plants in the market hall annex that also provides a seating area for customers to gather and socialize (Borough Market, 2018).

Vibrant markets contribute in direct and indirect job creation and employment opportunities. A large number of people are engaged with markets; either by directly working in the market, as retail traders or services providers (including cleaning, distribution, etc.) or by working on the supply chain starting the production and ending with the sale of the product or the service. The very idea of a concentration of traders increases both external and internal competition; the former refers to competition with other retail shops and the latter refers to competition between traders themselves. This results a healthy environment for customers as it leads to good deals in terms of quality and price. They can, thus, offer a variety of food and non-food products, at prices that are adapted to local residents' budgets (Costa et al., 2015).

Historic markets are also attractive destinations for local and international tourists, providing insights to local products, gastronomy, handicrafts, etc. They also are a representation of local ways of life. Thus, historic markets are efficient tools to boost and support the tourism industry that contributes in increasing growth of cities, as well as the promotion of local gastronomy and culinary traditions (Costa et al., 2015). Local markets become successful tourists' attraction when they maintain their souls and offer products and services that are useful and affordable for both the local community and the tourists. This balance is difficult but very important. In regeneration processes, some markets could fail to meet the regular needs of their local customers if they become too touristic or they could fail in their role as touristic attractions when tourists find the market soulless and inauthentic.

Markets can play a crucial role within their surrounding social circles. Public spaces surrounding markets, if inviting, accessible, comfortable places can provide spots for community gatherings where friends meet and neighbors greet, even beyond the market opening hours. Markets can be even used as venues for cultural events and activities related to the neighborhood. They can be promoters for healthy eating habits, offering fresh food 
and fresh products and become venues for educational programs for children, families and schools (Borough Market, 2018; Costa et al., 2015).

Historic markets can be, thus, used to regenerate their surrounding contexts especially in deprived neighborhoods. One example of such attempts is the Santa Caterina market in Barcelona, which was one of the historic markets' regeneration projects implemented by the Barcelona Institute of Municipal Markets. The market became an iconic building that offers several services for neighbors including meeting rooms, parking areas, 40 new apartments for the elderly and a pneumatic waste management system. The building is now a landmark in Barcelona and its surrounding context is transferred from being a deprived neighborhood into an upgraded, more fashionable place (Costa et al., 2015). It is now on the touristic map of the city of Barcelona.

\section{Historic markets as spaces for sociability}

Historic markets were always located in strategic spots within historic city centers. They were linked with central urban spaces, squares or piazzas and were connected with transportation systems that brought clienteles from various parts of the city. Thus, historic markets cannot be thought of as physical historic buildings without the strong social networks they create. In her book, "markets, places and cities," Seale describes markets as the nodes where "material and intangible flows - of people, goods, times, senses, affect come to rest, terminate, emerge, merge, mutate and/or merely pass through, and are contingent and relational to each other" (Seale, 2016). In other words, markets bring people together in economic and extra-economic exchanges (González, 2018).

While most research on the market tends to give more focus on the economic benefits of markets and how to maximize them, studying the social aspects of markets received less attention, even though it is widely accepted that markets do play a major role in consolidating the community ties and supporting social interactions. Yet, there is, a growing interest in using markets as catalysts for local regeneration and community initiatives.

Watson and Studdert (2006) traced four different social functions of markets. These social functions are: social interactions; social ties; social mixing across groups; and social inclusion. Social interactions range from the very minimal acts of greetings among acquaintances in the market to extended interactions among different users. Markets can also be venues for social ties when bonds grow between traders and regular shoppers over time or when friends and families trade together, creating a social life among traderstraders; traders-customers and customers-customers. In addition, markets could be venues where interactions across different socio-economic, demographic, ethnic groups take place. Markets can be opportunities for social inclusion especially for the most vulnerable or the marginalized groups who find markets as places to escape from their isolation in-home or elsewhere (Watson and Studdert, 2006; Hamza et al., 2017).

The employment and social life of market traders are intertwined. When social ties among traders thrive, they give considerable support to one another and the whole social atmosphere and vibrancy of the market are greatly enhanced. In markets with strong and articulate traders' association, needed changes are more likely to be addressed and implemented. In traditional and historic markets, stalls are usually passed down between parents and their decedents. Thus, in many cases, families of siblings and cousins would own stalls, usually in proximity of one another. In addition, given that traders represent the visible center of the market, their general attitudes and how they conduct themselves are highly reflected on how the market feels to the visitors (Watson and Studdert, 2006).

The positive relationship between traders and customers is also recorded to be a key reason of why shoppers prefer to shop in a particular market, even with no other social 
JHASS
3,3

222

exchanges on the market site. Markets represent social spaces for a wide range of different social groups of traders, shoppers, residents and tourists. In some cases, markets are also a social space par excellence for some particular segments in society, especially the elderly or other vulnerable groups (González, 2018). For such groups, the market might be their only chance to talk with someone all day, be it a trader or to another shopper (Watson and Studdert, 2006).

\section{Challenges facing regeneration of historic markets}

Historic market buildings face several challenges to maintain their historic social, economic and urban functions. In their study of the decline of market halls and covered markets; Jones, Hillier and Comfort, highlighted the changing working patterns and living conditions, as well as the expansion of towns, which was marked with decentralized residential areas and personal mobility (Jones et al., 2007). With the growing number of households with both adults in full-time employment, shopping preferences shifted toward a weekly stop shopping trip to accessible retail outlets that would also provide large parking spaces, usually free of charge (Jones et al., 2007). Historic markets, in contrast, are usually located in dense areas not accessible with cars and not connected with free parking areas.

From their side, small retailers in such historic markets find it difficult to maintain their customer base and increasingly difficult to attract new customers. In addition, a large number of historic markets also suffer from lack of investments to needed renovation and/or refurbishment either from local authorities, private companies that own and/or operate these markets or from market traders themselves. The latter groups are usually traders who are overwhelmed with securing their survival needs from week to week and cannot sacrifice their scarce earnings for the general improvements for the market (Jones et al., 2007). Adding to the previous general causes of decline some markets suffer from the lack of governing rules and struggle to protect historic uses against the invading uses of cheap imported goods, like in the case of Cairo markets (Hamza et al., 2017). This has led in many cases to the abandonment and de-investment in historic markets and left these buildings in decay.

Focusing on sociability, Watson and Studdert (2006) examined the different factors that might affect the sociability vibrancy of markets. They coined four factors that affect the sociability of markets: first, a market cannot be viable with no frequent customers. As the prime reason for a user to visit the market is to buy something, the economic success is of great relation with its success as a social space. This implies the importance of keeping the quality and variety of goods to attract different sectors of the community while maintaining competitive prices. Expanding dwell time for customers is an important factor to encourage customers' engagement. This can be done by providing a pleasant shopping environment, providing a café or eating outlet and attract people. Second, the easy accessibility of the market, its connection with public transportation and its proximity to parking areas is essential for private car users or for those who shop with heavy goods who cannot walk long distances. Third, the design of the market spaces, meaning the organization of the physical space shared by retailers and shoppers is a significant factor in the success of the interaction between shoppers-retailers, retailers-retailers and shoppers-shoppers, which is a key aspect in the success of a market as a social space. Also, the accessibility into the market, especially for those with wheelchairs or people with pushchairs, thus, the width of aisles is the main factor here. Fourth security and safety measures are also among the major features to encourage the viability of the market in terms of sociability (Watson and Studdert, 2006). Many of these factors represent challenges for decayed historic markets.

Despite these challenges and despite the long marginalization and decline of historic market buildings, several examples across the world have experienced regeneration and 
redevelopment (Seale, 2016). In many cases, however, regeneration attempts lead to the gradual or drastic change in the social make-up of the regenerated markets, where consumers and retailers might be displaced either because they are enforced to or because they find themselves not welcomed anymore (Dawson and González, 2015). A process that is usually referred to as "gentrification".

Gentrification is the process of replacement of the working or low-income class with higher income groups. A process that implies a change in the built environment (the spatial) and the new "wealthier" groups (the social) (González, 2018). A concept coined as retail gentrification.

Gentrification in historic markets can be carried out in several forms: it can be a result of the gentrification of the residential neighborhood surrounding a retail market, which is upgraded and gentrified to fit the needs of the new residents, or, markets can become, themselves, the flagship for the redevelopment of their surrounding context (González, 2018).

Although regeneration and gentrification bring positive impacts on the physical aspects of the market and its surroundings, they usually imply stories of displacement and exclusion of customers and/or traders who can no longer cope with the changes (Dawson and González, 2015). During the gentrification process, original retailers might become incapable to cope with the increase of rent, and thus, they usually have to choose between abandoning their stores or changing their products. In either case, original/frequent users of the market might eventually find themselves excluded. They will most probably find the new products unaffordable and it is very likely that they find themselves unwelcomed in their previously preferred shopping environment (Sullivan and Shaw, 2011). Thus, such interventions are usually induced with a displacement of traders, displacement of customers and displacement of products (González, 2018).

While the displacement of traders and products could be easily traced; the displacement of customers is more latent. Customers of the market - who frequent the market to buy products with reasonable prices and might in some cases become socially connected with traders or with other customers - are displaced when they find the products no longer affordable or the physical transformation of the market might reach a certain extent where they no longer recognize the place or find it as welcome as before (Dawson and González, 2015). Thus, an important question of any regeneration or redevelopment project for traditional markets is to investigate the impact of the regeneration project on the social tissue of the regenerated market and its surrounding.

Several models of markets' regeneration imply latently displacement of traders and/or customers and/or products. One example is the gourmet markets. Gourmet markets are those commercial spaces targeting tourists and high-income local residents, who are willing to pay, not only for the products they buy, which are usually labeled as "organic," "healthy," "natural," "locally produced," etc. but also for the gourmet experience offered by gourmet markets (Salinas Arreortua and Cordero Gómez del Campo, 2018). This model of gourmet markets is offered by several cities across the globe to attract mainly those with high buying powers. Examples include the San Miguel market (Madrid); Borough market (London); Ferry Building market place (San Francisco) and Central market (Valencia); etc.

With the increase of import/export of urban policies from a city to another, the gourmet market model became widely replicated. This is done, as illustrated by Peck and Theodore without deep consultation of the impact of the imported policy on the local political, economic and social characteristics in different settings (Peck and Theodore, 2010). It is important to note that the replication of a successful model may not guarantee successful outcomes. The simple copying of public policies that have worked successfully in one place, 
JHASS
3,3

224

does not guarantee the same success within a different context (Salinas Arreortua and Cordero Gómez del Campo, 2018). Thus, the implementation of any regeneration model should avoid the simple copy and paste and should include analysis of positive and negative expected outcomes, as well as feasibility studies.

\section{The case of Attaba market, Cairo, Egypt}

\subsection{Historic overview}

The second half of the 19th century and early decades of the 20th century marked a turning point in the expansion of the city of Cairo after decades of urban stagnation. In this period, the city was being modernized. Unlike several other examples in other cities, the first phase of modernization was achieved even before the intervention of western forces or colonial troops (Arnaud, 1998). With the grand project of the 19th century, Khedive Ismail wanted to establish a rival to European cities with their wide boulevards, squares, theatres and all other aspects of modernity including the construction of mass transportation networks and the application of modern hygiene measures. The new city of the 19th century in Cairo was established to the west of the traditional city, with several linking boulevards cutting through to link both cities (Raymond, 2001).

Establishing covered markets during the 19th century Cairo, was one of the tactics to provide modern shopping environments to compete with traditional Souqs. Like in Europe, the new building type aimed at replacing street markets and all their perceived negative implications with new buildings that promised to provide a clean, healthy environment for buying and selling, offering a variety of goods. Examples of covered markets established in Cairo at late 19th early 20th century include: Attaba market (1892), Bab ElHadid market (now fish market) (1910), Bab ElLouq market (1912) and Heliopolis market (circa 1907).

In parallel, as part of the modernization process, a modern mass transportation system was established between 1894 and 1917. It started when Baron Empain got the concession to a tramway network for the city of Cairo. As a start, an agreement was about the construction of eight lines, six of which start for Attaba al-khadra square, a few steps away from the Attaba market (Raymond, 2001). The other market buildings were also located in strategic places within the modern urban fabric and were all easily accessible with transportation networks, and thus, brought clientele form everywhere in the city.

Attaba market is the oldest 19th century covered market in Cairo. The market was built during the Khedieve Tawfiq reign (The Attaba Waqf Endowment Document, 1303 Hijri), on a land that was used until the Mohamed Ali era, as tombs known as AlManassra cemetery. Decades later, Khedieve Tawfik gave the land to the Endowments to establish the first covered market in Cairo. By the time of the construction of the market, its location was very strategic. It was located at Attaba al-Khadra Square, at the edge between medieval Cairo and the 19th-century city core. Moreover, the site was an upscale district where aristocrats, Princes and Pasha would reside in El Kadi (2012). Attaba Square was the convergence point of all tramway lines, a stop for various itineraries, thus, it was literary the heart of the city (Reynolds, 2012). By 1917, the Attaba market and Attaba square were within 15 to $20 \mathrm{~min}$ reach from the then farthest point in the city's built-up area (Reynolds, 2012).

The market building covers an area of $6,260 \mathrm{~m}^{2}$ and has four facades on AlAzhar, alMorgan, al-Attar and Mohamed Ali street. It is designed to have one main entrance on each of these 4 streets and 12 secondary entrances on both al-Morgan and al-Attar streets. The floor plan of the market building consists of two main corridors that intersect in a huge squarish central area covered with a trussed metallic roof. The two main corridors brought four pavilions, each had a specialty; butchers section, fish market, fruits and vegetables section and finally, spices and grocery (Reynolds, 2012). In total, 12 smaller corridors run 
from east to west, perpendicular to the longest corridor and parallel to the shorter one. These corridors are covered with a vaulted roof, higher than the height of the shops, which permits the light to illuminate the passages and at the same time decrease the weight of the roof.

Attaba square and its surroundings went through several drastic transformations, having great impacts on the market (Figure 1). Until 1869, the square was accessible only through Al-Muski street and the narrow alleys leading to Attaba square. Then four wide, straight streets were cut through the historic fabric linking the square to the other parts of the built areas, making it a real heart of the city. These linking streets increased the

Challenges in Attaba historic market accessibility and changed a lot in the morphology and future of the Square (Raymond, 2001).

In 1870, AbdelAziz street was opened up to link between the two contrasting urban worlds; old and modern Cairo. The street hosts several architecturally and historically significant buildings, including Omar Effendi, built-in 1905, one of the first department stores in Egypt and the Orient. In 1875, Mohamed Ali street was inaugurated, linking between Attaba square and the Citadel square. It was a monumental project that necessitated the removal of a huge amount of cubic meters of ruins. The street was compared to rue Rivoli in Paris, with its arcaded sidewalks that protected the strollers from sun and rain (Raymond, 2001). During the late 19th and early 20th century, the street was home for the most prominent musicians and artists who used to frequent its cafes. During the 1920s and 1930s, Prince Farouq street (later named as AlGuish Street), was cut to link Attaba square with Bab al-Shaeryea district and AlAzhar street was opened up, linking
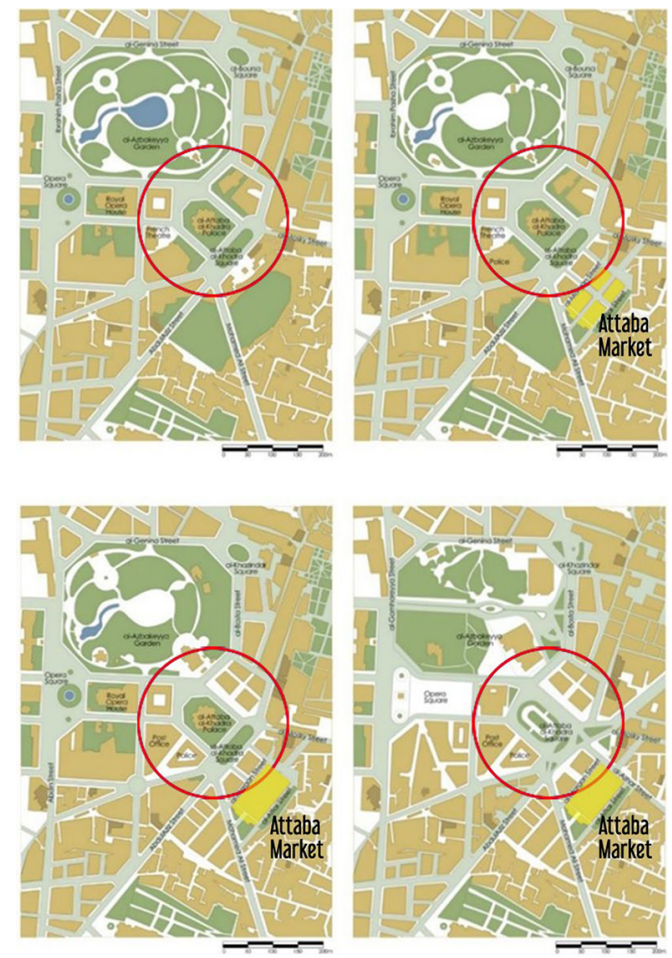

Figure 1.

Maps showing urban transformation in Attaba square surroundings for the dates 1874 (up left), 1890 (upright), 1933 (bottom left) and 1980

Source: The authors based on historic maps

(bottom right) 
JHASS 3,3

226

between Attaba square and AlAzhar Mosque, the very heart of Fatimid Cairo (Raymond, 2001).

In addition to the cut-through streets, Attaba square itself opened to a changing landscape of important commercial, governmental, entertainment buildings that played a crucial role in the socio-cultural, economic and political life of the city.

Initially, the current urban space of Attaba square was divided into two spaces Attaba alKhadra square and Azbak square, separated with a palace that Abbas Pasha I built for his mother in 1850. The palace was then replaced with the mixed court building, another new building type introduced to the urban fabric, to hear disputes between foreigners and Egyptians and foreigners of different nationalities (AlHadidi, 2017). The court was demolished in 1936, making way to unite, for the first time, the two spaces into one vast space of Attaba square. The square opened to several other important governmental buildings, including: the Khedieval post office (1888); the fire brigade (1904) and the police station (1904), all still exist until today.

Several premium commercial buildings were also located at Attaba square making it a commercial hub par excellence. The square opened to the Bazar Mourour building, which initially was established to monitor "transit trade" between Alexandria and Suez Ports, then with the inauguration of the Suez canal, the building use was converted to a vegetable market, until the inauguration of Attaba market in 1891. The building continued as a commercial building with several shops until it was demolished to make way for the cutting of Prince Farouq street (currently al-Guish street) (AlHadidi, 2017). In 1890, Qattawy bey has established two stories building that still exists till today is known as Halawa building. Just behind the Halawa store, Victor tiring built the famous tiring building, one of the earliest department stores. The nearby tiring building there was Stein building (1909), selling goods imported from England France and from its own factory in Vienna. Stein stores not only attracted customers residing in Egypt but also would deliver purchases to any part in Egypt or Sudan. Stein had other branches in Alexandria, Tanta, Minya and outside Egypt in Istanbul, Salonica and Vienna (Reynolds, 2012).

Historically, the square was also considered as a cultural hub; having AlAzbakeya garden and the national theatre, where the most famous singers and pioneers of theatre movement in Egypt used to perform (AlHadidi, 2017; El Kadi, 2012). On top of all, the western part of the square opened to the 1869 Khedival Opera House, established in light of la Scala Opera in Italy. Just behind the Opera house, in 1872, Matatias established an arcaded building similar to those in Clot Bey and Mohamed Ali street. Matatias building was famous with several cafes in its ground floor, where leading figures on the National Renaissance movement used to gather. The Opera remained the heart of the culture of the city until 1971 when it caught fire and was demolished. In the 1980s, the building was replaced with a multistory garage and commercial building. As for the famous Mattias café, it permanently closed its doors during the 1960 and was divided into several stores, then, it was said that whole building was affected by 1992 earthquake and then in 1999 it was completely demolished to make way for the construction of AlAzhar tunnel (AlHadidi, 2017).

\subsection{Current socio-spatial conditions of Attaba market and its context}

Currently, the Attaba market is owned by the Egyptian Endowment Authority. The building is officially recorded in the Endowment records as "Souq AlKhedewy Tawfiq bel Attaba AlKhadra" (trans. Khedieve Tawfiq market in AlAttaba AlKhadra square). As in the case of all the buildings it owns, the authority is responsible for everything related to the building, from the collection of rents revenues to the maintenance of the building. Yet, 
the outside of the building is under the responsibility of the Cairo Governorate as the local authority and the Endowment as the owner. Recently, a General Administration for the Preservation of the Heritage of Cairo, a section stemmed from Cairo Governorate was established dedicated to the preservation of the heritage of Cairo. They have several attempts in the revitalization of parts of Khedival and Historic Cairo. According to the interview with the head of the General Administration for the Preservation of the Heritage of Cairo, the Governorate is interested to revitalize the Attaba market and other markets in Cairo, but they are complicated as they require the intervention with a numerous number of different social groups, sometimes with contradicting visions.

In Egypt, buildings are listed and protected according to one of three laws: first, a structure might be listed as a monument under the Antiquities Law no.117/21983. All buildings that are as old as one hundred years or more. According to this law, registered buildings are considered as monuments and are affiliated to the Ministry of Antiquities. Any interventions in monuments should be done with the approval and under the supervision of the Ministry of Antiquities. Second, a building of value can be registered according to the law regulating the demolition of non-dilapidated buildings and establishments, and the preservation of architectural heritage, Law no. 144/2006 (NOUH, 2006, the law of regulating the demolition of non-dilapidated buildings and establishments, and the preservation of architectural heritage no. 144/2006 2006). Finally, the Law 119/2008, is concerned with areas of value. According to this law, the National Organization of Urban Harmony (NOUH), is authorized to create a list of buildings and districts of peculiar value and draft decrees for their protection. NOUH is also authorized to coordinate among different stakeholders (NOUH, 2008, Law no. 119/2008 National Organization of Urban Harmony 2008).

Attaba market is registered as a peculiar building of value under law 114/2006, under registration number (03220000032) (NOUH, 2020a, 2020b). Besides, as it is located exactly on the edge between historic Cairo and Khedivial Cairo, Attaba square falls within the boundaries of Khedivial Cairo, while Attaba market buildings fall within the boundaries of historic Cairo, according to Law 119/2008 (NOUH, 2020a, 2020b, Registration of Khedival Cairo as Heritage Area of Value n.d.).

Even though the building is listed and even though it falls exactly between two listed areas of value, currently, the market and its immediate context suffer major encroachments, threatening the value of the market and the surrounding buildings of value.

The four facades of the market are completely covered with a new layer of fixed on extrusions and almost completely hiding the historical facades. The wide entrances are narrowed down by new extrusions and signage (Figure 2). Extrusions are not only exclusive to the external facades but also on the interior of the market. Shops extend their properties, narrowing the corridors' width to a great extent (Figure 3). This affects customers' circulation in the market and also blocks the loading and unloading of goods throughout the day (Figure 4). Needless to mention that these encroachments also put the market at risk, as they hinder the circulation and escape, in case of emergency. The complete absence of firefighting systems in the market endangers users' lives along with this significant building.

The clean, healthy shopping environment promised to be offered by the building is now of the past. Natural airflow is a major problem in the building. Clerestory windows are usually blocked with non-central air conditions compressors or their opening mechanism is not working due to lack of maintenance. Furthermore, no public toilets available at the market, neither for traders nor for customers. 


\section{JHASS \\ 3,3}

\section{8}

Figure 2.

Attaba market from the outside-current conditions

Figure 3.

Internal

encroachments,

Attaba market, Cairo
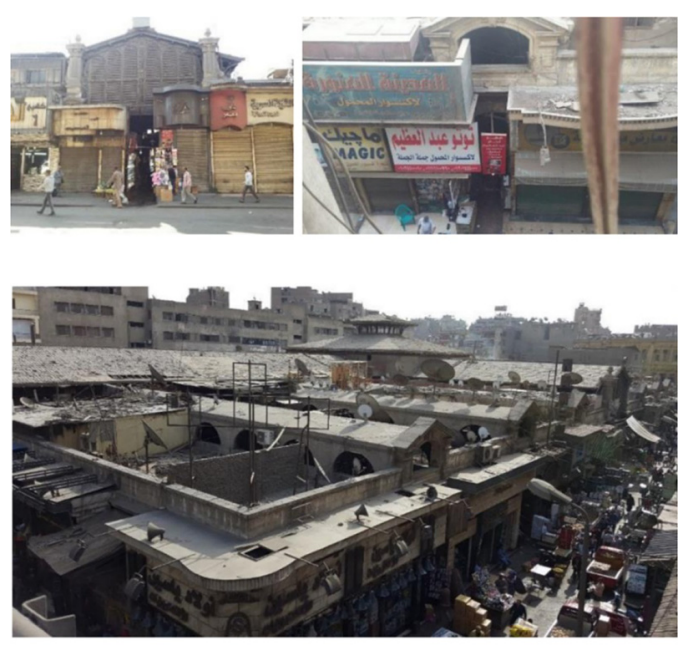

Source: The authors
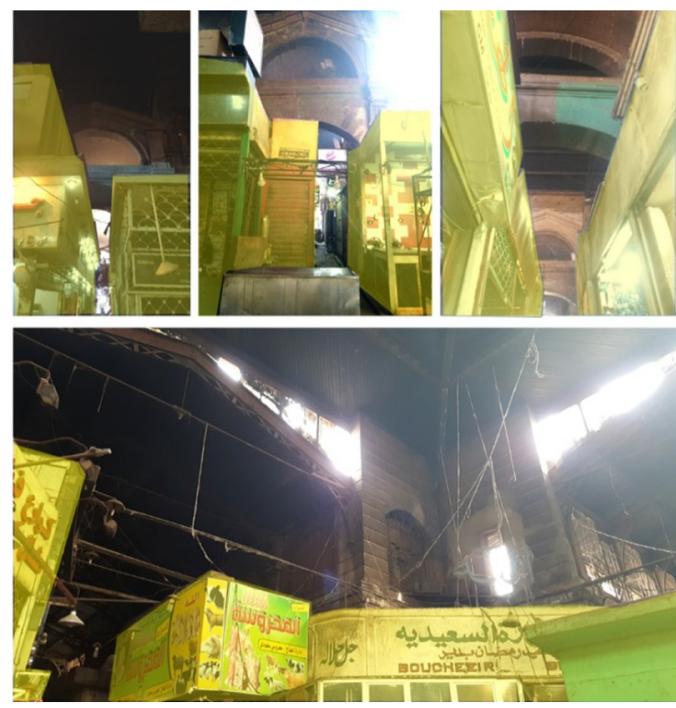

Source: The authors

The historic social role used to be played by the covered market is under threat. Based on interviews with traders conducted by the research group in 2016, 2017 and 2018 the team found out that the composition of the shopkeepers now consists of two major groups: the first group is original tenants shopkeepers, who have inherited the lease of their shops. The majority of this group maintain the original use of their shops, usually related to culinary functions. They are well aware of the building value and they mostly care about it. The 
second group is the newcomers, called as the "ghoraba" by the original tenants (ghoraba literary means: the strangers). Most of them would change from one trade to another according to profit circumstances, shifting mainly to imported mobile phone accessories and refurbishing their units with no general guiding rules to protect the heritage building. The intensity of the gap between these two groups grows year after year. This rupture between shopkeepers is also present between shoppers. Original shopkeepers find it difficult to maintain their customers or to attract new ones, while new shopkeepers manage to attract a completely different type of users, mostly wholesale customers rather than local individuals from the surrounding area.

Decaying current conditions of the market cannot be assessed in isolation from the decaying conditions of the surrounding context. Several studies referred to the major problems of Khedival Cairo that include densification processes, rapid urban growth, a decline in residential uses, dismantling of the tramway network and giving priority to vehicular traffic against the pedestrian movement, (El Kadi, 2012) these problems contributed negatively on the market. Even the vast space of Attaba square is burdened with Al-Azhar flyover linking between the 19th-century core and Al-Azhar Street, designed in the intention to decrease traffic problems regardless of all social, aesthetical and environmental implications (Figure 5).

Though the area has always been and still is a busy commercial district, however, the various, sometimes contradicting, economic overall orientation, linked with the political shifts in the country, were synchronized with a change in the consumption attitudes in the area. While the surrounding historic department stores are left in decay, informal street markets are growing (Plate 1). Starting the 60s and 70s with the exodus of foreigners and minority groups and their replacement with the new bourgeoisie, the social strata of the area

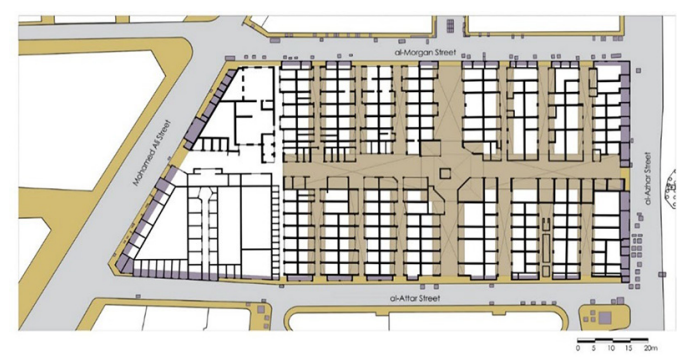

Figure 4. Highlighted corridors mark the original width of alleys before shops extrusions

Source: The authors narrowing alleyways

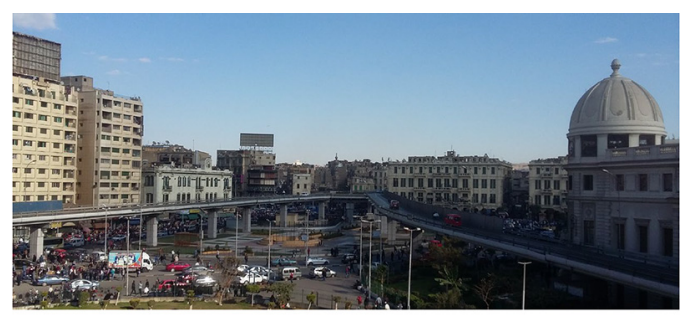

Figure 5. Al-Azhar flyover Source: The authors' collection over Attaba square 
JHASS
3,3

230

changed to a great extent. The surrounding urban spaces lost their appeal as social spaces. All these macro and micro changes in the physical and non-physical aspects had a crucial impact on the Attaba square and consequently on the Attaba market.

\section{Regeneration framework for Attaba market and its surrounding context}

In the previous parts, the study illustrated historic markets as potential anchors to regeneration processes, highlighting markets leading role in sustainable urban development. Yet, the study also showed the several challenges that face the regeneration of this building type in general and focused on those challenges facing the Attaba market in particular. Based on the previous discussion, this section presents a proposed framework for the regeneration of the Attaba market and its surrounding context.

As illustrated, covered markets and market halls are linked with several different stakeholders with a wide range of visions and perceptions. At the same time, historic markets have always been strongly connected with their environmental, economic and social contexts. Thus, regenerating historic markets in decaying settings cannot be done without bringing together the different stakeholders with their ideas and visions for the market's regeneration, while also putting the surrounding physical and non-physical context into consideration. The proposed framework deals with two parts; the first is concerned with the mechanism of bringing stakeholders together for better management and sensitive decisions for the market, and the second deals with the action fields that need be taken into consideration to reach a sustainable regeneration and urban development, together with a guiding model for prioritizing implementation of these actions.

Given that there exist several stakeholders concerned with the market, sometimes with different or clashing visions for its regeneration, the first step toward a better future for Attaba market is to establish a board of trustees that includes representatives of various stakeholders. The aim of this trustee is to find a common ground for all those who are concerned with the market and to ensure continuous participation in the decision-making process. As already discussed, regeneration projects and rehabilitation of historic buildings that follow top-bottom approaches, meaning that the local authority together with the investor applies their vision for the regeneration without including the addressed social community, usually lead to gentrification and cause several problems that probably threaten the socio-spatial quality and integrity of this building type.

Thus, to maintain proper regeneration of the market, the proposed board of trustees for Attaba market will include representatives of the Endowment Authority (the building's owner); representatives of the "General Administration for the Preservation of Heritage"

Plate 1.

Contrast between deserted historic department stores and busy streets with street vendors (left) tiring building, (right) stein building
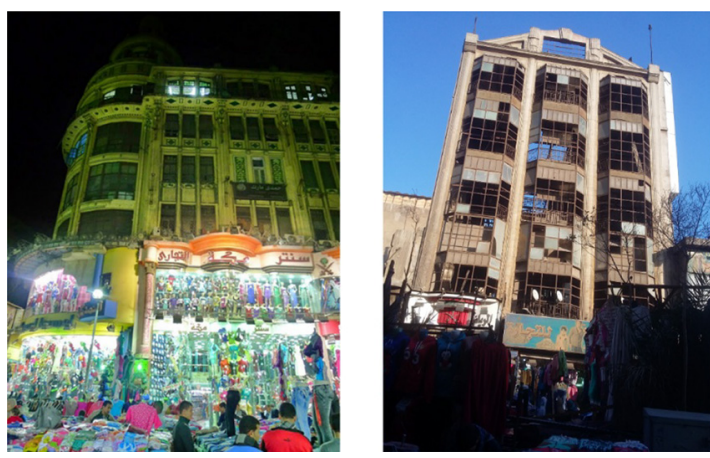
Cairo Governorate - (as the administrative body that is responsible for the outside of the building and its surrounding context); representatives of Cairo District and Cairo Local Authority, representatives of the National Organization of Urban Harmony, representatives of current traders of the market and, a new proposed society that gather all "friends of Attaba market." This society must include representatives of customers (old frequent customers and new customers) and should also include, economists and funders, architects, urban designers, historians among others (Figure 6). Coordination among the different partners is to be managed by the National Organization of Urban Harmony as stated by the law.

It is essential to work on the capacity building of members of the proposed board of trustees. Both on the level of the administrative representatives, as well as on the level of stallholders and retailers (Figure 6):

- On the administrative level, capacity building programs should prepare administrative representatives to manage such very specific building types with its requirements and essentials for regeneration. Capacity building programs need to also address administrative obstacles in managing the market and link with other international successful cases such as the Barcelona model for market regeneration. More importantly, the capacity building for the administrative level will aim at bringing together several efforts done by the various official bodies and authorities to make sure a synchronization between efforts is achieved.

- On the level of stallholders, it is essential to offer training courses to update the trader's marketing skills, as well as strengthening their bonds with the building and surroundings. Traders' capacity building programs can be also related to improving their soft skills in dealing with customers and with local and international tourists. Training could also include updating the stallholders' marketing tools including social media and the internet in general, together with enriching their knowledge concerning their products and tools to update quality and variety.

There is a variety of management systems that are internationally adopted to legally manage and operate historic markets. Focusing on publicly owned market buildings, one of three management systems can be adopted as follows: a public management system; a private management system; or a mix of a public and private management system. In all cases, the market remains publicly owned and in all cases, the operator must abide by all official rules and regulations to preserve the authenticity and integrity of the structure. Specifically: the Antiquities law-117/1983; the Preservation of Heritage law-114/2006; and

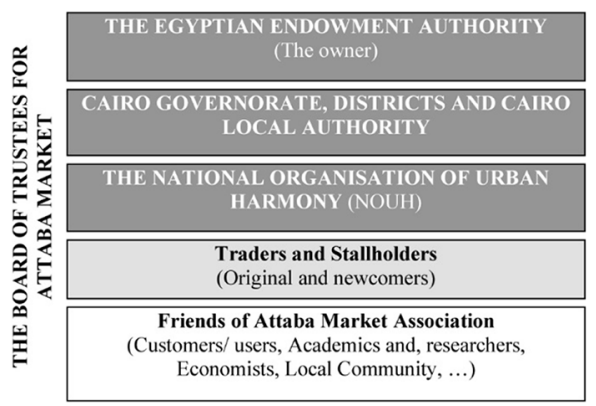

ON THE ADMINISTRATIVE LEVEL

Capacity building for management of historic covered markets

Capacity building for regenerating historic covered markets Administrative issues and obstacles linked with covered markets.

Exposure with international successful experiences in regenerating historic covered markets, ....

ON THE LEVEL OF TRADERS AND STALLHOLDERS

Updating traders' marketing skills, as well as strengthening their

bonds with the building and surrounding.

Improving traders' soft skills in dealing customers and local and international tourists.

Updating stallholders' marketing tools including social media and the internet in general.

Enriching the stallholder's skills concerning their products and how to update quality and offer variety...
Challenges in Attaba historic market

231

Source: The authors

Figure 6.

The board of trustees and the proposed capacity building programs 
JHASS 3,3

the Urban Harmony law-119/2008, that were previously discussed in the paper. In any of the previously mentioned management systems, the owner (in this case the Endowment Authority) assigns representatives to monitor and make sure that the operator strictly abides by the rules. At the same time, the Board of Trustees must be included in all major decisions concerning the market.

The difference between the three management systems, however, is the degree of intervention of the public body in the control over the space:

(1) In the public management system: an autonomous public body is assigned for the management of the market.

(2) In the private management system: usually, the public owner ensures the application of rules and regulations and intervenes in the management with a varying level of details, while the daily management of the market is delegated to one or several private operators (Costa et al., 2015). This could be achieved by the concession of the market management to a private operator, who leases the spaces and assumes management and its costs. Alternately, the traders form a legal association with which the local council signs an agreement to entrust them with the management-based agreed-upon terms and conditions.

(3) The mix of a public-private management system is a mix of both previously mentioned systems.

To attain a sustainable regeneration of the market, the three pillars of sustainability should be tackled by the board of trustees and the operator of the market. This includes measures on the environmental, economic and social levels. The three levels described in Table 1 are complementing one another and their success helps to achieve sustainable regeneration.

On the environmental level, the physical aspects of the market and its surrounding should be ameliorated. This includes but is not limited to enhancing accessibility to the building, through mobility studies, that consider connecting the building with the public transportation network; improving pedestrianization in the buildings' surrounding; and providing nearby car parking lots. Accessibility into the market should be also ameliorated, this includes bringing inner alleyways to their original width, removing all extrusions and illegal interventions, redesign of stalls, renovation, conservation and refurbishment of the building. The environmental aspects also include fixing clearstory windows mechanisms to enhance the air quality and airflow inside the building, it also includes the design and implementation of an efficient waste management plan. Moreover, providing services for market users is essential, this includes WCs, seating areas and eating outlets among other services that would help make the market a pleasant, socially vibrant, environment. These physical improvements will, in turn, expand users' dwell time in the market, and hence, help the economic and social aspects to prosper.

On the economic level, the board of trustees, the operator and the owner should have extensive discussions to tackle monetary and non-monetary aspects related to the market. The non-monetary issues include considering elaborating measures to help protect original traders and help them maintain their trade while giving opportunities for newcomers to cope with original traders. The monetary issues include maintaining the profit from the market at the same time maintaining the variety of products sold in the market while keeping competitive prices to attract different types of users. The board of trustees, the operator and the owner need to consider fundraising issues and probably integrate between public and private funds. The private sector can be 




encouraged to invest in this kind of project by incentives of tax reduction or tax exemption. The presence of both economists and representatives of local authorities among the board of trustees will help in this attempt.

On the social level, the board of trustees and the operator need to seek channels to ameliorate the spatial conditions of the market to enhance opportunities of social functions including social interactions, strengthening social ties, encouraging social mixing and social inclusion. A reconciliation between old traders and new traders is important to strengthen relationships among Attaba market traders. This as has been illustrated, is reflected on how the market feels to the visitors. Furthermore, the stronger the traders association is, the more likely needed changes are successfully addressed and implemented. The board of trustees could hold regular meetings at Attaba market to discuss problems a search for applicable solutions, the friends of Attaba market society could also agree on establishing a suitable platform to communicate in what concerns the market. Table 1 highlights major action fields that need to be tackled for the regeneration of the market building. The list cannot be considered as an exhaustive list, it is rather a guiding list. The list should be revised when the board of trustees is active.

Given that it is impossible to implement the required actions for regeneration all at once, it is important to consider a prioritization decision of fields of action. This means that required actions should be classified and arranged according to aspects including the urgency of the action, which depends on several factors, including the degree of threat it represents for the structure and the community, together with the action emergent importance for the regeneration process. The prioritization of action should include also the required financial resources to implement the action; the amount of time needed for achievement; whether it is linked to other projects or other 
JHASS
3,3

Figure 7.

A guiding tool for prioritization of action fields of interventions, the authors prerequisite actions. Figure 7 shows a guiding tool to order the prioritization and responsibility schedule that can be filled in by the board of trustees/operators of the market.

\section{Conclusion}

Historic market buildings represent key opportunities for the sustainable development of their contexts. After long decades of decay of historic markets across the world, 19th and early 20th-century historic markets have been rediscovered in several western countries as tourists' attraction, food meccas and nucleus for sustainable regeneration. Developing countries, in turn, can rediscover their assets of historic covered market buildings and profit from the different opportunities they offer. The regeneration of this special building type as socio-spatial key buildings, however, proved a complex, multidimensional process.

Historic covered markets in Cairo are underused assets. They represent a rare building type dating back to the late 19th/early 20th century that have always played a major role in the environmental, economic and social lives of their surrounding contexts. Cairo's covered markets are still maintaining their function as market buildings, but they are currently facing several challenges that put them under threat. Thus, they are in urgent need for responsive, conscious and sensitive regeneration interventions. As historic covered markets have been always strongly connected with their environmental, economic and social contexts; regeneration of these markets cannot be done without considering the impacts on and from their surrounding context.

The paper focused on the Attaba market, the oldest 19th century covered market in Cairo, a listed building located between two registered areas of value. The building, which represents a rare existing prototype in Cairo is currently facing fast displacement of its traders, customers and products and is also facing severe social and spatial problems that threaten its significance and put several challenges for its regeneration.

The paper proposed a framework that can be applied to regenerate the Attaba market and its surrounding context. The framework addressed the issue of stakeholders' involvement under the umbrella of a board of trustees. It also addressed the mechanisms of linking this board of trustees with the different possible management systems, all after applying building capacity programs to both traders and administrative representatives. The framework also highlighted major action fields to be addressed to achieve sustainable urban development of the market and its surrounding. Finally, the framework proposed a guiding tool useful in specifying prioritization tasks for implementation. When tested, the framework can be also adjusted and applied to the other historic covered markets in Cairo.

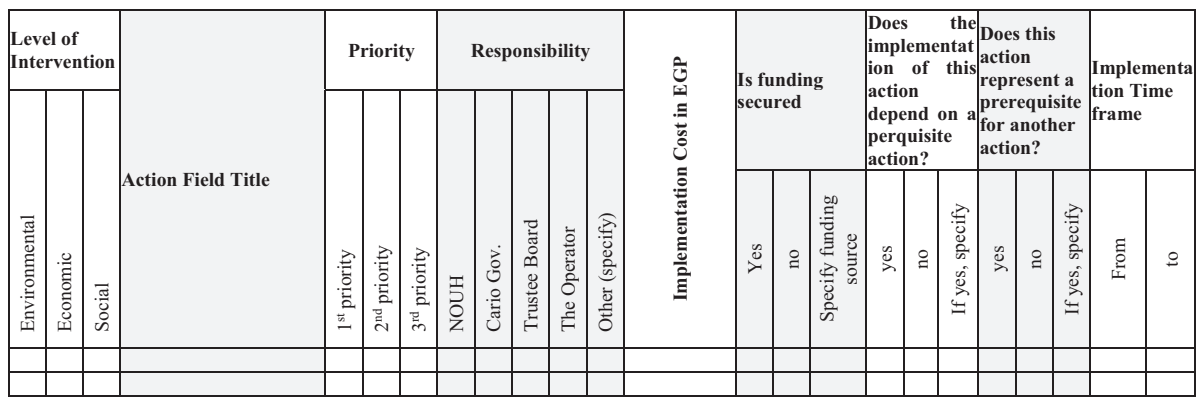




\section{References}

AlHadidi, F.H. (2017), دراسات في التطور لعر اني لمدينة القاهرة (trans. Studies in the Urban Development of Attaba historic Cairo), General Egyptian Book Organization, Cairo.

Arnaud, J.L. (1998), Le Caire: Mise en Place D'une Ville Moderne 1867-1907: Des Intérêts du Prince Aux Sociétés Privées, Actes Sud, Arles.

Borough Market (2018), "Borough market”, available at: http://boroughmarket.org.uk/ (accessed 01 June 2018).

Coleman, P. (2007), Shopping Environments: Evolution, Planning and Design, Routledge.

Costa, N., Mackay, M., Martín Perez, O., Navarro, G., Partridge, A., Portinaro, A. and Scheffler, N. (2015), Urban Markets: Heart, Soul and Motor of Cities, City of Barcelona Institut Municipal de Mercats de Barcelona (IMMB), Barcelona.

Dawson, G. and González, S. (2015), "Traditional markets under threat: why it's happening and what traders and customers can do", London, available at: http://eprints.whiterose.ac.uk/102291/

El Kadi, G. (2012), Cairo: Center in Movement, Institut de Recherche pour le Développement (IRD Editions), Marseille.

González, S. (Ed). (2018), "Contested markets contested cities”, Gentrification and Urban Justice in Retail Spaces, Routledge, London.

Guàrdia, M. and Luis Oyón, J. (2015), "Introduction: European markets as makers of cities”, Making Cities through Market Halls. Europe, 19th and 20th Centuries, Museu d'Història de Barcelona: Institut de Cultura: Ajuntament de Barcelona, Barcelona, pp. 11-71.

Hamza, N., ElKerdany, D., Pendlebury, J., Imam, S., AlSadaty, A. and ElSerafi, T. (2017), "Sustained liveability: a framework beyond energy-conscious building conservation of market halls", International Journal of Architectural Research: Archnet-IJAR, Vol. 11 No. 3, pp. 119-131, doi: 10.26687/archnet-ijar.v11i3.1381.

Jones, P., Hillier, D. and Comfort, D. (2007), "Changing times and changing places for market halls and covered markets”, International Journal of Retail and Distribution Management, Vol. 35 No. 3 , pp. 200-209, doi: 10.1108/09590550710735059.

NOUH (2006), "The law of regulating the demolition of Non-Dilapidated buildings and establishments, and the preservation of architectural heritage no. 144/2006", available at: www.urbanharmony. org/download/pd (accessed 1 January 2019).

NOUH (2008), "Law no. 119/2008 national organisation of urban harmony", available at: www. urbanharmony.org/download/pdf/low.pdf (accessed 1 January 2019).

NOUH (2020a), available at: http://urbanharmony.org/search_places.asp?x=1 (accessed 2 January 2019).

NOUH (2020b), "Registration of khedival Cairo as heritage area of value", available at: http:// urbanharmony.org/download/pdf/khdweic\%20cairo\%20\%20boundries \% 2019-1-2011.pdf (accessed 2 January 2019).

Peck, J. and Theodore, N. (2010), "Mobilizing policy: models, methods, and mutations", Geoforum, Vol. 41 No. 2, pp. 169-174.

Raymond, A. (2001), Cairo: City of History, Wood, W. (Ed.), The American University in Cairo Press, Cairo.

Reynolds, N. (2012), A City Consumed: Urban Commerce, the Cairo Fire, and the Politics of Decolonization in Egypt, Stanford University Press, Stanford, CA.

Salinas Arreortua, L.A. and Cordero Gómez del Campo, L. (2018), "Gourmet markets as a commercial gentrification model: the cases of Mexico city and Madrid”, in González, S. (Ed.), Contested Markets Contested Cities. Gentrification and Urban Justice in Retail Spaces, Routledge, London, pp. 86-98.

Schmiechen, J. and Carls, K. (1999), The British Market Hall: A Social and Architectural History, Yale University Press, New Haven and London.

Seale, K. (2016), Markets, Places, Cities, Routledge, London. 
JHASS

3,3

236

Sullivan, D.M. and Shaw, S.C. (2011), "Retail gentrification and race: the case of Alberta street in Portland, Oregon", Urban Affairs Review, Vol. 47 No. 3, pp. 413-432.

The Attaba Waqf Endowment Document (1303), Hijri. " حجة وقف سوق العتبة برقم 3711 سجلات الباب العالى Waqf Endownment Document for Attaba Market”, Cairo.

Tweed, C. and Sutherland, M. (2007), "Built cultural heritage and sustainable urban development", Landscape and Urban Planning, Vol. 83 No. 1, pp. 62-69, doi: 10.1016/j. landurbplan.2007.05.008.

Watson, S. and Studdert, D. (2006), Markets as Sites for Social Interaction: Spaces of Diversity, The Policy Press and Joseph Rowntree Foundation, Bristol.

\section{Further reading}

Pendlebury, J. (2010), "Conservation and regeneration: complementary or conflicting processes? The case of grainger town, newcastle upon tyne", Planning Practice and Research, Vol. 17 No. 2, pp. 145-158, doi: 10.1080/02697450220145913.

Scharabi, M. (1989), Kairo: Stadt Und Architektur im Zeitalter Des Europäischen Kolonialismus, Ernst Wasmuth, Tübingen.

\section{Corresponding author}

Aliaa AlSadaty can be contacted at: aliaa_alsadaty@yahoo.com

For instructions on how to order reprints of this article, please visit our website: 